\title{
Application of green marketing mix of beauty products on sales through purchase decisions as intervening variable
}

\author{
Danang Satrio*, Siti Yunitarini, Nila Rizqiani \\ Department of Management, Faculty of Economics and Business, Universitas Pekalongan, \\ Pekalongan, Indonesia
}

\begin{abstract}
Article History
Received : 1 June 2021

Revised : 21 July 2021

Accepted : 21 August 2021

Published : 27 August 2021

Keywords:

Green marketing mix, purchase

decision, sales

*Corresponding author:

danangsatrio3003@yahoo.com

DOI:

10.20885/AMBR.vol1.iss2.art1
\end{abstract}

\begin{abstract}
Public awareness in Indonesia in responding to global warming has increased significantly. Increased public awareness plays an important role in providing challenges and opportunities for companies that provide goods or services to create products that are in accordance with their wishes. The challenge is to guarantee that the goods or services provided are safe for consumers and friendly and do not damage the environment. The concept of green marketing mix refers to the satisfaction of customer needs, wants, and desires in relation to the maintenance and preservation of the environment. Discussions on environmental issues in developed countries have been initiated and developed since the 1990s. Green marketing is a marketing concept used by companies to achieve the main goal of making a profit. Green marketing in the process is an act of integrating broad activities, which include product modifications, changes to the production process, changes to packaging, to changes to advertising. Based on this phenomenon, this study aims to find out how much influence the application of the green marketing mix has on sales.
\end{abstract}

\section{Introduction}

Awareness of the environment has become a very important issue in this era of globalization. Discussions on environmental issues in developed countries have been initiated and developed since the 1990s. Consumer buying habits and behavior are currently directed to the issue of environmental protection. In the United States, several poll studies have consistently shown that the majority of the US population views themselves as environmentalists (Shrum, 1995).

Garbage is increasingly becoming a big problem when the amount of waste is increasing and it is difficult to recycle. Based on statistical data, the second rank of domestic waste producer in Indonesia is the production of plastic waste of 5.4 million tons per year (Antara News, 2014). It is undeniable that the use of plastic and plastic bags continues to increase from year to year. Data from the Deputy for Pollution Control at the State Ministry of the Environment (KLH) states that each individual produces an average of 0.8 kilograms of waste in one day with 15 percent of which is plastic (Istantia et al., 2016).

Shrum (1995) also featured a research conducted by Advertising Age magazine which was held by Yankelovich Clancy Shulman which found that $70 \%$ of all respondents said that purchasing decisions for a regular product or brand were influenced by environmentally friendly messages in advertising, labels, product packaging. and green marketing of a company (Angeline et al., 2015).

Consumers who have concern for the environment will decide to purchase the product or service to meet their needs (smart consumer). Consumers will seek information about the product to be purchased before making a purchase decision. Decision making to purchase goods and services often involves the roles of two or more parties (Aldoko et al., 2016). When consumers are interested in a product and a feeling or desire arises to buy, it can be said that the product has a high level of sales. The green marketing concept has a marketing mix variable that creates high sales volumes that encourage consumers to buy environmentally friendly products.

To capture new opportunities that arise and to ensure a better standard of living with sustainable development, the concept of green marketing emerged as a concern for the issues of 
environmental damage which was then used by the company as one of the strategies in its marketing (Rahayu et al., 2017).

Along with the development of science, the concept of expansion of marketing emerged. Especially since the emergence of a book entitled "The Green Marketing Manifesto" by John Grant has made the business world's sensitivity to the environment higher (Grant, 2009). Green marketing or commonly called environment marketing is developing in line with the public's attention to environmental issues, so that people demand the responsibility of business people in carrying out business activities. Green marketing is a marketing concept used by companies to achieve the main goal of making a profit. Green marketing includes ideas in marketing management that are applied based on environmental issues. Green marketing in the process is an act of integrating broad activities, which include product modification, changes in the production process, changes in packaging, to changes in advertising (Arimbawa \& Ekawati, 2017). Rahman, et al. (2017) states that green marketing focuses on saving resources on earth in terms of production, operations, packaging, distribution, environmental compatibility with performance, affordability, convenience and environmental safety.

The concept of the green marketing mix was first introduced by Bradley in the late 1980s. Other researchers who identified several aspects of the green marketing mix, for example, Islam (2018), explain how products are greened. Agustin, et al. (2015), explain how prices are greened. Islam (2018), explains how promotions and places/distribution channels are greened. However these researchers only touch on specific areas and concentrate more on other things in their studies, and this is one possible explanation why there is a theoretical gap, no single researcher explores how green marketing mix is, but green marketing mix is often practiced and proposed by consultants.

The phenomenon in facing challenges when it will attract public interest is by implementing an environmentally friendly marketing strategy (green marketing). Many companies take advantage of environmental conservation as a new concept and opportunity in developing their business because environmental awareness becomes a potential business and generates more efficient profits. Sales related to green marketing is a marketing concept used by companies to achieve the main goal of making a profit. Factors that can affect sales are the condition and ability of the seller, market conditions, capital, the condition of the company's organization. Based on this phenomenon, this study aims to find out how much influence the application of the green marketing mix has on sales through purchasing decisions as an intervening variable.

\section{Literature Review and Hypotheses Development}

\section{Green Marketing}

In the 1990s, the green marketing agenda began to develop as a new topic related to individual consumer motivation related to effectiveness, cooperative behavior and strategic alliances where green marketing is a marketing program that covers a broad range of environmental-based marketing which includes company policies, practices and marketing procedures that explicitly focus on environmental friendliness with the aim of generating income and providing exchanges or transactions that satisfy organizational and individual goals (Arimbawa \& Ekawati, 2017).

The American Marketing Association (AMA) in (Syahbandi, 2012) defines green marketing in three different definitions: Retailing definition, namely green marketing is the marketing of products that are considered safe for the environment. Social marketing definition, namely green marketing is the development and marketing of products designed to minimize negative impacts on the environment or to improve quality. Then the last environmental definition, namely green marketing, is an effort made by organizations to produce, promote, package, and claim products in a way that is very sensitive or responsive to ecological concerns. The application of Green Marketing in business processes can trigger companies to care more about the environment. environment, therefore the implementation of Green Marketing in a company can make the company a company that has a high concern for the environment and Green Marketing as a company's business orientation (Darmadi, et al. 2013). 
Green marketing mix or green marketing mix is a different marketing mix with traditional/conventional marketing mix. Although the marketing mix indicators remain the same, the green marketing mix is more of a marketing mix that involves environmental factors as its main orientation (Arimbawa \& Ekawati, 2017). Developing the concept of green marketing mix (green marketing mix), cannot be separated from the traditional 4P concept (product, price, place, promotion) except with a number of additional components that are closely related to the intent of green marketing itself and other very influential things (Ferrinadewi, 2005).

The concept of green marketing mix refers to the satisfaction of customer needs, wants, and desires in relation to the maintenance and preservation of the environment (Hanifah et al., 2016), but the challenge for marketers is the creative use of the green marketing mix, which includes green products, green price, green place and green promotion. This concept was first introduced by Bradley in the 1980s, in its development many researchers suggested that the green marketing mix be studied more deeply. Some writers mark the many elements of green marketing and also consider it a real and complete strategy. Green Marketing mix manipulates the four elements of the marketing mix (product, price, promotion, and distribution) to sell products and services offered from the advantages of environmental stewardship formed from waste reduction, energy efficiency improvement, and reduced toxic emission release. These advantages are often approached through life-cycle analysis (LCA) which measures the environmental impact on the product at all stages of the product life cycle (Angeline et al., 2015). The following are the elements/components of the green marketing mix:

1. Green Products

Green Products or environmentally friendly products are products that prioritize long-term safety for users and the environment. Darmadi et al. (2013) state that the ecological goals of environmentally friendly products are to reduce resource consumption and pollution and increase conservation of scarce resources. The company always tries to innovate the development of products that do not harm the environment in order to anticipate adverse impacts on the environment. People are also getting smarter in choosing items that are safer to use. Harahap (2015) argues that green products are products that do not pollute the environment, do not waste resources or can be recycled. Green products help save energy to maintain and increase natural environmental resources and or reduce or eliminate the use of toxic substances, pollution and waste.

Haryadi (2009) defines green products are usually durable, not harmful to health, packaging made of recycled materials. This is in line with Islam (2018) which argues that green products are efforts to minimize waste during the production process in addition to maximizing products made while meeting environmental friendly requirements. Green products themselves must have product quality that is durable, in the sense that they are not easily damaged, do not contain toxins, are made from materials that can be recycled and have minimalist packaging. So, hypothesis formulation from this are green products stimulate consumer doing decision to buy and then at the end it can improve sales to the company itself.

2. Green Price

Hidayat and Zuliarni (2014) empirically shows that price is the most valid information as an indicator of the quality of a product. Furthermore, price is an important element in the marketing mix, most customers are willing to pay a premium price if there is an additional perception of the value of the product. This value can improve performance, efficiency, design, visual appeal and taste or because of other features of green products such as longer life expectancy and harmlessness (Islam, 2018). According to Queensland Government that the green price or environmentally friendly price is the amount of money spent by consumers to get environmentally friendly products. Haryadi (2009: 33) states that most customers are willing to pay a premium if there is an additional perception of product value. Aldoko et al. (2016) explains the general reason why consumers are willing to pay a premium price for environmentally friendly products is because they believe in the quality of a product and they care about environmental problems. So, hypothesis formulation from this are green price 
stimulate consumer doing decision to buy and then at the end it can improve sales to the company itself.

3. Green Place

Green place involves the choice of a company's distribution channel that minimizes environmental damage and makes a product always available so that it can have an impact on customers or consumers. Very few customers really only want to buy a product because of its eco-friendliness. Sellers who want to achieve success in selling environmentally friendly products should position their products widely in the market so that they can be more recognized (Syahbandi, 2012). Green distribution channels each company must decide how to make the product available to consumers. Environmentally friendly distribution channels must pay attention to the convenience of consumers in obtaining products without having to spend a lot of energy and fuel. Several companies that produce environmentally friendly products sell their products through authorized distributors to maintain premium product quality (Pamikatsih, 2019). Syahbandi (2012) argues that green distribution channels have characteristics, namely product packaging for transporting to distribution sites must minimize waste and use of raw materials. Product transportation to distribution points should be aimed at reducing environmental damage, such as reducing energy consumption and reducing pollution. So, hypothesis formulation from this are green place stimulate consumer doing decision to buy and then at the end it can improve sales to the company itself.

4. Green Promotion

Companies need to develop an integrated communication approach that engages in certain aspects of company and product specifics on environmental and social responsibility issues. The strategies and slogans used by the company must be correct based on research and information. Information must be communicated coherently and consistently to customers and other stakeholders. The main key and success of a green marketing strategy is credibility. Smart green product sellers will be able to emphasize the credibility of environmentally friendly products by using sustainable marketing as well as communication tools and practices (Syahbandi, 2012). Green promotion consists of several parts, namely promotions that discuss the relationship between products/services and the biophysical environment, promotions that promote environmentally friendly lifestyles by highlighting products or services, and promotions that present a corporate image of environmental responsibility (Dwipamurti, et al., 2018). Priyanka and Septrizola (2019) states that the marketing mix itself can be done with: advertising, sales promotion, public relations, personal selling, direct marketing. So, hypothesis formulation from this are green promotion stimulate consumer doing decision to buy and then at the end it can improve sales to the company itself.

\section{Buying Decision}

Putripeni et al., (2014) argue that purchasing decisions are an evaluation process carried out by prospective consumers to combine their knowledge of the choice of two or more alternative products and choose one of them. Consumers who like or are positive about a product will tend to have a strong desire to choose and buy the product they like. On the other hand, if the consumer is negative towards a product, then the product will usually not be considered as a purchase choice, and it is not uncommon to even convey his dislike to his friends, relatives or neighbors (Aldoko et al., 2016).

Kotler and Armstrong (2008) state that the purchasing decision process consists of five stages, namely: problem recognition, information search, evaluation of alternatives, purchase decisions, and post-purchase behavior. At the purchase decision stage, consumers actually make a purchase. However, sometimes in this decision making there are several factors that can influence the decision making so that it can change the purchase intention. Rahayu et al., (2017) state that the purchase decision taken by the buyer is actually a collection of a number of decisions. According to Kotler and Armstrong (2008) states that in carrying out purchase intentions, consumers can form five sub-decisions: 1) Brand, 2) Dealer/seller, 3) Quantity/number of products, 4) Time of purchase, 5) Payment method. So, hypothesis formulation from this is intention to buy can force 
potential consumer to do the real buying activities and then it can affect directly to improving sales for the company. It can be implied that buying decision variable becomes mediator between green product, green price, green place, and green promotion to influence sales variable of the firm.

\section{Sales}

Sales is the process by which the seller satisfies all the needs and desires of the buyer in order to achieve sustainable benefits for both the seller and the buyer and that are beneficial to both parties (Tjiptono, 2005). According to Tjiptono and Chandra (2017), sales management is planning, directing, equipping, assigning, determining the route of supervision, payment and motivation as tasks given to the workforce.

The general sales objectives owned by the company are: 1) Achieve sales volume, 2) Get a certain profit 3) Support the company's growth. Based on the description above, it can be concluded that the general purpose of the company in conducting sales activities is to achieve sales volume, get maximum profit to support company growth. Sales cannot be ignored in the marketing function because of the sales process then profits will be created, in order to support the survival of the company.

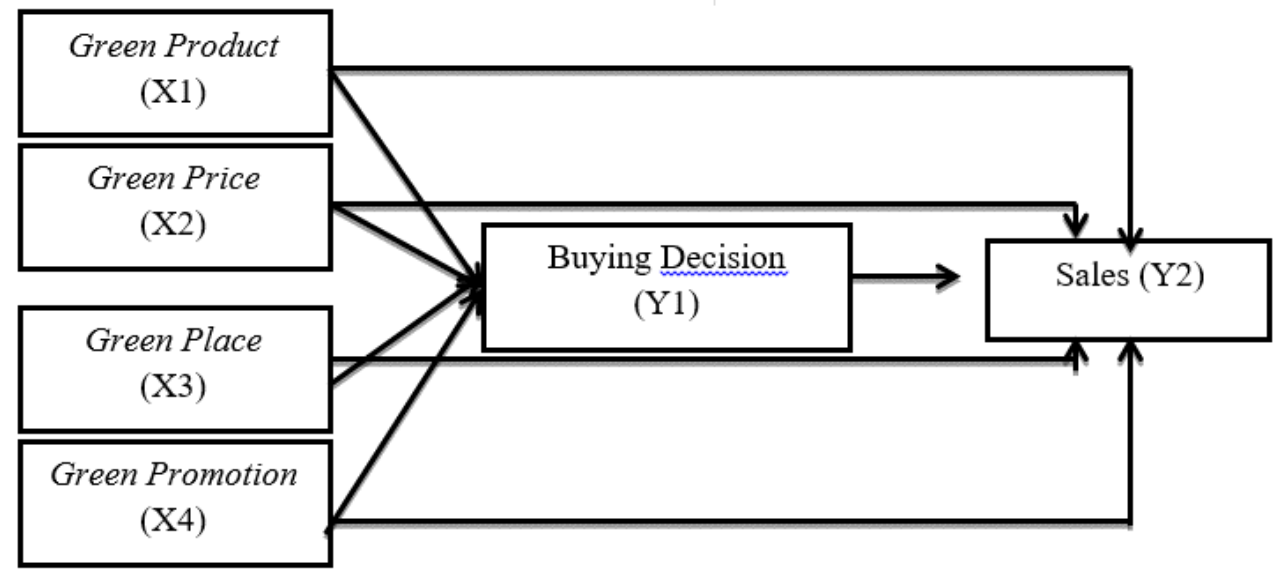

Figure 1. Research Model

\section{Research Methods}

The type of research used in this research is descriptive research or also called explanatory research with a quantitative approach. According to Verma (2012) descriptive research is research that aims to describe the data collected in order to solve research problems and or test hypotheses. Meanwhile, according to Verma (2012) states that (explanatory research) is research that explains the causal relationship between research variables through hypothesis testing that has been formulated. This study will provide an explanation of the causal relationship or cause-effect between the green marketing mix variable and the sales variable through purchasing decisions (Hair, et al. 2015).

So in this study the population is taken, namely people who buy and used products with an unidentified amount. Determination of sample size is carried out by using the Estimated Interval method, this method is used if the population is not identified or is often called an infinite population, namely the size of the population whose members cannot be clearly identified (Sekaran and Bougie, 2010). So for this adequacy of sample size used for 80 respondents. This study uses purposive sampling due to simplify and speed up sample collection. Data collection is done by using a predetermined instrument or data collection tool, and by using a census method or method (recording all elements that are the object of research/population), sampling (recording some of all elements/members of the population to be sampled), case studies (only by observing one or several elements whose population is not clear to be investigated in depth (McQueen and Knussen, 2013). 


\section{Results and Discussion}

\section{Result of Validity test}

Validity is testing the validity of each question item which is carried out by correlating the item score with the total score which is the sum of each item score (Ghozali, 2009). The validity test is carried out on all statement items that are distributed to 100 respondent buyers and users of Herborist products and the results will be tested for indicates whether or not a questionnaire item is valid. The statement scores were processed using the help of the IBM SPSS Statistics 20 program.

\section{Result of Reliability Test}

Table 1. Reliability Testing Result

\begin{tabular}{lccc}
\hline \multicolumn{1}{c}{ Variable } & Cronbach Alpha & Cutoff Value & Information \\
\hline Green Product & 0,679 & 0,600 & Reliable \\
Green Price & 0,603 & 0,600 & Reliable \\
Green Place & 0,604 & 0,600 & Reliable \\
Green Promotion & 0,706 & 0,600 & Reliable \\
Buying Decision & 0,756 & 0,600 & Reliable \\
Sales & 0,714 & 0,600 & Reliable \\
\hline
\end{tabular}

Source: Primary data processed

Based on the table 1, it can be seen that all variables in this study ranging from green product variables, green prices, green places, green promotions, purchasing decisions, sales, have Cronbach's alpha values exceeding the standard criteria that have been set, which is 0.600 or reliable, so it can be concluded that all variables in this study are feasible to be used as research sources. Path analysis is a statistical technique that describes the causal relationship or effect of a group of independent variables (cause/exogenous) on the dependent variable (effect/endogenous) (Ghozali, 2016).

\section{Result of Hypotheses Testing}

After testing the model, hypothesis testing is carried out in order to know the direct and indirect effects between variables. The proposed hypothesis will be concluded by calculating the path coefficient value and significance for each path studied. The results of all proposed hypotheses will be explained as follows:

Table 2. Direct Effect on Purchase Decision (Y1)

\begin{tabular}{ccccc}
\hline Model & B Coefficient & Std. Error & $\mathbf{t}$ & Sig. \\
\hline (Constant) & 8,725 & 2,123 & 4,110 &, 000 \\
Total_X1 &, 225 &, 110 & 2,294 &, $024 *$ \\
Total_X2 &, 117 &, 087 & 1,334 &, 185 \\
Total_X3 &, 003 &, 107 &, 031 &, 975 \\
Total_X4 &, 064 &, 108 &, 596 &, 552 \\
\hline
\end{tabular}

Sample size $=80$

Significant at $*<0,05 ; * *<0,01 ; * * *<0,000$

Source: Primary data processed

Table 3. Direct Effect on Sales (Y2)

\begin{tabular}{ccccc}
\hline Model & B Coefficient & Std. Error & $\mathbf{t}$ & Sig. \\
\hline Constant) & 3,935 & 2,222 & 1,771 &, 080 \\
Total_X1 &, 145 &, 115 & 1,263 &, 210 \\
Total_X2 &, 050 &, 091 &, 550 &, 584 \\
Total_X3 &, 395 &, 112 & 3,528 &, $001 * *$ \\
Total_X4 &, 373 &, 113 & 3,314 &, $001^{* *}$ \\
\hline
\end{tabular}

Sample size $=80$

Significant at $*<0,05 ; * *<0,01 ; * * *<0,000$

Source: Primary data processed 
Table 4. Indirect Effect on Sales (Y2) Through Purchase Decisions (Y1)

\begin{tabular}{ccccc}
\hline Model & B Coefficient & Std. Error & $\mathbf{t}$ & Sig. \\
\hline (Constant) &,- 819 & 2,070 &,- 395 &, 693 \\
Total_X1 &, 008 &, 102 &, 079 &, 937 \\
Total_X2 &, 013 &, 079 &, 167 &, 868 \\
Total_X3 &, 393 &, 096 & 4,091 &, $000^{* * *}$ \\
Total_X4 &, 338 &, 097 & 3,492 &, $001^{* *}$ \\
Total_Y1 &, 545 &, 092 & 5,909 &, $000^{* * *}$ \\
\hline
\end{tabular}

Sample size $=80$

Significant at $*<0,05 ; * *<0,01 ; * * *<0,000$

Source: Primary data processed

\section{The effect of green products on purchasing decisions}

In this study, the positive effect means that the green product is directly proportional to the purchase decision. Because the marketing strategy that influences consumers in making decisions is the product marketing mix that is evaluated by consumers. Green consumers are new types of consumers who are currently competing to get green products to meet their needs. The need for green consumers to meet the needs of green products, indicates the closeness between green products and purchasing decisions. Therefore, green products have a positive effect on purchasing decisions. Meanwhile, it has a significant effect because green product is one of the green marketing mix variables which is included in the external factors that cause consumer concern for environmentally friendly elements. This concern for environmental friendliness has resulted in increased consumer purchasing power for products containing natural ingredients (Risyamuka and Mandala, 2015). Green products have an influence on purchasing decisions seen from the awareness of consumers to consider environmental issues in their buying behavior, so Herborist not only maintains the quality of its products, but more than that is able to create new product innovations that are reliable, environmentally friendly and understand the needs the customer. Based on the results of the study, the results of the calculation of the hypothesis test that the green product has a t_count of 2.294 with a significance level of 0.024 and using a significance limit of 0.05 (alpha 5\%), then the hypothesis is accepted. In this study, green products have a direct influence on purchasing decisions. So it can be concluded that green products have a positive and significant influence on purchasing decisions for Herborist products.

Research in the field proves that buyers and users of Herborist products among the public agree that the products offered by Herborist have advantages or advantages in terms of form, safety, durability and comfort felt by consumers. So that the green product variable has a positive and significant effect on purchasing decisions. The results of this study are in line with research conducted by Rahman et al., (2017) which states that the green product variable directly has a positive and significant effect on purchasing decisions.

\section{The effect of the green price on purchasing decisions}

The results of this study indicate that the green price has a positive effect on purchasing decisions, meaning that the green price is directly proportional to purchasing decisions. In general, respondents said that they were satisfied with the price set by the company, because they could see and feel for themselves the better quality compared to other products they had bought. And with product prices that can still be reached by all groups, consumers will no longer hesitate to make purchasing decisions (Putripeni, et al. 2014). While the effect is not significant even though at an affordable price, consumers still do not know in detail about the environmental message conveyed by Herborist products. Customers tend to use price as an indicator of quality and are willing to spend more on 'valuable' products. So as long as the quality of Herborist's products is guaranteed to be good, it can affect high consumer purchasing power, in this case consumers feel that they have received safe products, have taken part in protecting the environment and have received products with quality and benefits that are comparable to the price, Herborist can still set a higher price. higher than its competitors. Based on the results of the study, it was found that the calculation 
results of hypothesis testing that the green price has a t_count of 1.334 with a significance level of 0.185 and using a significance limit of 0.05 (alpha 5\%), then the hypothesis is not supported. So it can be concluded that the green price has a positive and insignificant effect on the purchase decision of Herborist products.

The price of the product if it is more expensive does not necessarily attract consumers to decide to buy the product, this is because environmentally friendly products at premium prices do not necessarily give a good perception of the value of the product. In this study, the green price does not have a direct influence on purchasing decisions. So that this variable does not have a significant effect on purchasing decisions. In this case the green price variable may require other variables to mediate the purchasing decision, this research is supported by Priyanka and Septrizola (2019) which states that the green marketing variable has no significant effect on the purchasing decision structure variable. This means that the amount of green marketing in the form of green pricing has no significant effect on the structure of consumer purchasing decisions.

\section{The effect of green place on purchasing decisions}

The results of this study state that green place has a positive effect on purchasing decisions because the more outlets/stores that provide Herborist products, the easier it is for consumers to get these products, Herborist products have positioned their products widely in the market making consumers easy to reach so that green places have a positive influence on buying decision. While the effect is not significant, even though Herborist's products have widely positioned their products in the market, the company in applying the environmentally friendly concept to outlets has not been able to fully meet the criteria. The influence of green place on purchasing decisions is seen from how easy it is for Herborist product providers to be reached or in other words, environmentally friendly products can position their products widely in the market so that they can be more recognized, because the closer and easier it is for consumers to get products, the more consumers who will be interested and decide to buy Herborist products (Hidayat and Zuliarni, 2014). Based on the results of the study, the results of the calculation of the hypothesis test that the green place has a t_count of 0.031 with a significance level of 0.975 and using a significance limit of 0.05 (alpha 5\%), then the hypothesis is not supported. So it can be concluded that the green place has a positive and insignificant effect on the purchasing decisions of Herborist products.

Consumers will decide to buy a product if the green place conditions are met. So Herborist should improve service in its outlets by providing a variety of complete body care and cosmetic equipment. Turn the outlet into a one stop shopping place, where customers can quickly get all the tools they need easily. The number of outlets was also increased to make it easier for potential customers to reach. But in this study green place does not have a direct influence on purchasing decisions (Pamikatsih, 2019). So that this variable does not have a significant effect on purchasing decisions.

\section{The effect of green promotion on purchasing decisions}

The results of this study indicate that green promotion has a positive effect on purchasing decisions, meaning that green promotion is directly proportional to purchasing decisions. When the promotion carried out by the company is successful in providing knowledge of environmentally friendly products and can convey the implied message of each use of product materials issued by Herborist through advertising, it can influence consumers to buy the product. Meanwhile, green promotion has no significant effect on purchasing decisions because even though the promotions carried out by Herborist are good, consumers still do not care about the environmentally friendly messages conveyed by these products (Harahap, 2015). Based on the results of the study, it was obtained that the calculation results of hypothesis testing that green promotion had a t_count of 0.596 with a significance level of 0.552 and using a significance limit of 0.05 (alpha 5\%), then the hypothesis was rejected. So it can be concluded that green promotion has a positive and insignificant effect on purchasing decisions for Herborist products. Lack of consumer knowledge of environmental messages and lack of promotions that reflect activities in communicating product advantages cause consumers not to feel persuaded to buy them. In this study, green promotion did 
not have a direct influence on purchasing decisions. So that this variable does not have a significant effect on purchasing decisions.

In this case, the green promotion variable may require other variables to mediate purchasing decisions, such as research conducted by Hanifah et al., (2016) which states that green marketing in the form of green promotion has no significant effect on the structure of consumer purchasing decisions, due to lack of information available. given to the public and consumers regarding green marketing, so that people do not understand the advantages that can be obtained by buying these green products.

\section{The direct effect of green products on sales}

The results of this study indicate that green products have a positive effect on sales because the presence of environmentally friendly products is the answer to the needs of consumers who are aware and care about the environment so that it affects sales which are increasing (Dwipamurti et al., 2018). While the effect is not significant because even though sales increase but sometimes consumers only buy products when they need/want it. Based on the results of the study, the results of the calculation of the hypothesis test that the green product has a t_count of 1.263 with a significance level of 0.210 and using a significance limit of 0.05 (alpha 5\%), then the hypothesis is not supported. So it can be concluded that green products have a positive and insignificant effect on sales of Herborist products.

In this study, green products do not have a direct effect on sales. So this variable does not have a significant effect on sales. In this case the green product variable may require other variables to influence sales, but in this study it is not supported by previous research that has been proposed, meaning that this research is not in accordance with research conducted by Agustin et al., (2015). This study states that the green product variable has no significant effect on sales.

\section{The direct effect of the green price on sales}

The results of this study state that the green price has a positive effect on sales because with different quality consumers can get natural products, the price of Herborist products that claim that their products are environmentally friendly has an affordable price or the same as products that are not environmentally friendly (Aldoko, et al. 2016). While the effect is not significant because there are still some consumers who want Herborist products at discounted prices. Based on the results of the study, it was obtained that the calculation results on hypothesis testing that the green price had a t_count of 0.550 with a significance level of 0.584 and using a significance limit of 0.05 (alpha 5\%), then the hypothesis was not supported. So it can be concluded that the green price has a positive and insignificant effect on sales of Herborist products.

For general products, price reductions can increase sales, while for products that carry a prestigious image, price increases will increase sales. But if an environmentally friendly product does not provide values and insights into environmental friendliness so that consumers do not know the advantages of the product, it will not increase sales because consumers are reluctant to pay more for environmentally friendly products purchased. In this study, green prices do not have a direct effect on sales. So this variable does not have a significant effect on sales. In this case the green price variable may require other variables to influence sales, but in this study it is not supported by previous research that has been proposed, meaning that this study is not in accordance with research conducted by Agustin et al., (2015). This study states that the green price variable has no significant effect on sales.

\section{The direct effect of green place on sales}

The results of this study indicate that green place has a positive effect on sales, meaning that Herborist products have occupied the national market where their products have been disseminated in the market. While the green place has a significant effect, it means that many consumers know the outlets where they sell Herborist products, thereby increasing sales (Arimbawa and Ekawati, 2017). Based on the results of the study, it was found that the results of the calculation of the hypothesis test that 
the green place had a t_count of 3.528 with a significance level of 0.001 and using a significance limit of 0.05 (alpha 5\%), then the hypothesis was supported. So it can be concluded that the green place has a positive and significant influence on sales of Herborist products.

Ease of reaching locations can increase product sales. This green place system can be achieved because the product is always available in the market, so it can have an impact on customers or consumers. In this study, green place has a direct influence on sales. So this variable has a significant influence on sales. This is in line with research conducted by Haryadi (2009) which states that business location has a positive and significant effect on sales realization.

\section{The direct effect of green promotion on sales}

The results of this study indicate that green promotion has a positive effect on sales, meaning that green promotion which is used as a promotional media for Herborist products has used appropriate communication practices so that it can attract consumers through its sales. While the significant effect means that consumers who use Herborist products already know the message conveyed by the product through promotions, so that many consumers buy and use the product. Based on the results of the study, it was found that the calculation results of hypothesis testing that green promotion has a t_count of 3.314 with a significance level of 0.001 and using a significance limit of 0.05 (alpha 5\%), then the hypothesis is accepted. So it can be concluded that green promotion has a positive and significant influence on sales of Herborist products.

Companies that have concern for consumers and the environment will apply continuous communication intensively in increasing public understanding of the environmentally friendly products they sell. And the promotion of Herborist's products has succeeded in convincing consumers to be environmentally friendly. In this study, green promotion has a direct influence on sales. So this variable has a significant influence on sales. This is in line with research conducted by Darmadi et al., (2013) which states that the independent variable (sales promotion costs) has a significant influence on sales volume.

\section{The influence of purchasing decisions on sales}

The results of this study indicate that purchasing decisions have a positive and significant effect on sales, meaning the higher consumer interest in purchasing a product, the stronger consumer perceptions of sales made by the company. Consumers who have purchased and used Herborist's products must know the product through sales made by the company. Based on the results of the study, it was obtained that the calculation results of hypothesis testing that the purchase decision had a t_count of 2.831 with a significance level of 0.006 and using a significance limit of 0.05 (alpha $5 \%$, the hypothesis was accepted. So it can be concluded that purchasing decisions have a positive and significant influence on sales of Herborist products. Factors to increase sales are by knowing customer desires and recognizing customer needs, by knowing and determining market share, capital, and determining sales strategy. In this study, purchasing decisions have a direct influence on sales. So this variable can have a significant influence on sales. In this study, the relationship between purchasing decisions and sales is as explained by Istantia et al., (2016), which states that one of the factors to increase sales is knowing the wants and recognizing consumer needs, this is done so that our products are right on target, so consumers can immediately decide to buy if they directly meet the product as needed. However, this study states that the purchase decision variable has a significant effect on sales.

\section{The indirect effect of green products on sales through purchasing decisions}

The results of this study indicate that purchasing decisions have not been able to mediate between green products and sales because environmentally friendly products in sales have no effect on purchasing decisions, when consumer perceptions of product sales are good, it reflects that the product has good quality. This does not mean that you have to go through a purchase decision first before you can say that environmentally friendly products are good in sales. This means that the direct effect of green products on sales is greater/higher than having to go through a purchase 
decision first. The results of the path analysis in this study indicate that the green product has a positive and indirect effect on sales through the purchase decision of Herborist products. This is proven by the regression coefficient value of green product to sales of 0.013 while the value of the coefficient of green product to sales with purchasing decisions as an intervening variable is 0.000 which means that purchasing decisions are not able to mediate between green products and sales. Green products or products that have environmentally friendly elements are able to create good sales because consumers feel that the product has several advantages but the green product has not been able to lead consumers to make purchasing decisions (Angeline, et al. 2015). In this case, the research is not supported by previous research or can be said to be different research. However, this study states that indirectly the green product variable does not have a significant effect on purchasing decisions on sales.

\section{The indirect effect of the green price on sales through purchasing decisions}

The results of this study state that purchasing decisions have not been able to mediate between green prices and sales because to increase sales the company must be able to provide prices that are relatively easy to reach by all groups. However, purchasing decisions have not been able to influence the green price on sales. This means that the direct influence of the green price on sales is greater/higher than having to go through a purchase decision first (Ferrinadewi, 2005). The results of path analysis in this study indicate that the green price has a positive and indirect effect on sales through the purchase decision of Herborist products. This is evidenced by the value of the green price regression coefficient on sales of 0.002 while the value of the green price coefficient on sales with purchasing decisions as an intervening variable is 0.000 which means that purchasing decisions are unable to mediate between green prices and sales. Green prices that have environmentally friendly elements usually tend to be more expensive but provide good product quality so consumers will be willing to spend a lot of money for products with good quality, this will increase sales, but the green price has not been able to lead consumers to make decisions purchase (Rahayu, et al. 2017). In this case, the research is not supported by previous research or can be said to be different research. However, this study states that indirectly the green price variable has no significant effect on purchasing decisions on sales.

\section{The indirect effect of green place on sales through purchasing decisions}

The results of this study indicate that purchasing decisions have not been able to mediate between green places and sales because places that involve environmentally friendly aspects such as the location and distance of outlets that are easily accessible by consumers will directly affect sales, the more people are interested in visiting outlets that provide Herborist products. This means that the direct influence of the green place on sales is greater/stronger than having to go through a purchase decision first (Rahman, et al. 2017). The results of the path analysis in this study indicate that the green place has a positive and indirect effect on sales through the purchase decision of Herborist products. This is proven by the value of the green place regression coefficient on sales of 0.106 while the green place coefficient on sales with purchasing decisions as an intervening variable is 0.000 which means that purchasing decisions are not able to mediate between green places and sales. Green places or locations/places with environmentally friendly elements can create sales if the location of the place to sell applies the concept of being environmentally friendly, the product can be reached by consumers, then consumers will be satisfied with a sense of comfort in the location where they sell. However, the green place has not been able to lead consumers to make purchasing decisions. In this case, the research is not supported by previous research or can be said to be different research (Risyamuka and Mandala, 2015). However, this study states that indirectly the green place variable does not have a significant effect on purchasing decisions on sales.

\section{The indirect effect of green promotion on sales through purchasing decisions}

The results of this study state that green promotion has not been able to mediate between green promotions on sales because promotions that involve environmentally friendly aspects will 
definitely directly affect sales, and do not have to go through a purchase decision first before promotions by the company are said to be good in terms of sales. This means that the direct influence of green promotion on sales is greater/higher than having to go through a purchase decision first (Islam, 2018).

The results of path analysis in this study indicate that green promotion has a positive and indirect effect on sales through purchasing decisions for Herborist products. This is proven by the value of the green place regression coefficient on sales of 0.106 while the green place coefficient on sales with purchasing decisions as an intervening variable is 0.000 which means that purchasing decisions are not able to mediate between green places and sales. Green promotion or promotions that have environmentally friendly elements can create sales if the company carries out vigorous promotions or campaigns for products with the aim of loving the environment, it will increase sales high but the green promotion has not been able to deliver consumers to make purchasing decisions (Syahbandi, 2012; Tjiptono and Chandra, 2017). In this case the research has not been supported by previous research or it can be said that it is a different study. However, this study states that indirectly the green promotion variable does not have a significant effect on purchasing decisions on sales.

\section{Implication and Conclusion}

The application of Green Marketing in business processes can be a trigger for companies to care more about the surrounding environment, therefore the implementation of Green Marketing in a company can make the company a company that has a high concern for the environment and Green Marketing as a company's business orientation (Shrum, 1995). Green marketing mix or green marketing mix is a different marketing mix with traditional/conventional marketing mix. Although the indicators of the marketing mix remain the same, the green marketing mix is more of a marketing mix that involves environmental factors as its main orientation (Agustin et al., 2015).

In future research, it is necessary to pay more attention to the variables in the study that have an insignificant effect, especially to variables that have an insignificant negative effect. The promotions carried out are still lacking so that consumers do not have a broader insight about Herborist products. Stores/Outlets/Outlets that provide Herborist products that are spread out are still lacking so they have not really reached their consumers. Herborists are also expected to take part in sponsoring environmental and social activities. For further research that examines the application of green marketing, it can be developed by adding the marketing mix to green marketing such as process, physical evidence, and people (Arimbawa and Ekawati, 2017; Istantia et al., 2016; Rahman et al., 2017). Moreover, in this study, researchers only used four marketing mixes, namely product, price, place, and promotion. So that further research can produce better and more complete research.

\section{References}

Agustin, R.D., Kumadji, S. and Yulianto, E. (2015). Pengaruh green marketing terhadap minat beli serta dampaknya pada keputusan pembelian (Survei pada konsumen non-member Tupperware di Kota Malang), Jurnal Administrasi Bisnis, 22(2), 1-10.

Aldoko, D., Suharyono and Yuliyanto, D. (2016). Pengaruh green marketing terhadap citra merek dan dampaknya pada keputusan pembelian (Survei pada mahasiswa Fakultas Ilmu Administrasi 2012/2013 Universitas Brawijaya yang melakukan pembelian produk tupperware), Jurnal Administrasi Bisnis, 40(2).

Angeline, M.E., Ngangi, C.R., Laoh, E.O.H., and Sondakh, M.L. (2015). Hubungan green marketing terhadap pilihan konsumen (Studi kasus pada the Body Shop Manado), Cocos: Jurnal Ilmiah Fakultas Pertanian Universitas Sam Ratulangi, 6(8).

Arimbawa, I.G.S., and Ekawati, N.W. (2017). Pengaruh penerapan green marketing terhadap citra merek dan keputusan pembelian produk, E-jurnal Manajemen Unud, 6(5), 2582-2608. 
Darmadi, D., Suharyono, and Latief, W.A. (2013). Pengaruh promosi terhadap penjualan (Studi kasus PT. Astra Internasional TBK-TSO cabang Soetoyo Malang), Jurnal Administrasi Bisnis, 2(1).

Dwipamurti, I.G.A.N., Mawardi, M.K., and Nuralam, I.P. (2018). The effect of green marketing on brand image and purchase decision (Study on consumer of Starbucks Café Ubud, Gianyar Bali), Jurnal Administrasi Bisnis, 61(3).

Ferrinadewi, E. (2005). Atribut Produk yang Dipertimbangkan dalam Pembelian Kosmetik dan Pengaruhnya pada Kepuasan Konsumen di Surabaya, Jurnal Manajemen dan Kewirausabaan, 7(2), 139-151. https://doi.org/10.9744/jmk.7.2.pp.\%20139-151

Ghozali, I. (2009). Ekonometrika: Teori, Konsep, dan Aplikasi dengan SPSS 17. Semarang: Badan Penerbit Universitas Diponegoro.

Ghozali, I. (2016). Aplikasi Analisis Multivariate dengan Program IBM SPSS 23, edisi 8. Semarang: Badan Penerbit Universitas Diponegoro.

Grant, J. (2009). The Green Marketing Manifesto. West Sussex, UK: John Wiley \& Sons Ltd.

Hair Jr., J.F., Celsi, M.W., Money, A.H., Samouel, P., and Page, M.J. (2015). Essentials of business research methods, second edition. USA: M.E. Sharpe/Taylor \& Francis Group.

Hanifah, A.D., Arifin, Z., and Hidayat,K. (2016). Pengaruh bauran pemasaran berwawasan green marketing terhadap keputusan pembelian (Survei pada pembeli yang menghuni Perumahan Ijen Nirwana Malang), Jurnal Administrasi Bisnis, 32(2).

Harahap, D.A. (2015). Analisis faktor-faktor yang mempengaruhikeputusan pembelian konsumen di Pajak USU (PAJUS) Medan, Jurnal Kenangan dan Bisnis, 7(3), 227-242.

Haryadi, R. (2009). Pengaruh strategi green marketing terhadap pilihan konsumen melalui pendekatan marketing mix (Studi kasus pada The Body Shop Jakarta). Tesis Program Pascasarjana Universitas Diponegoro.

Hidayat, R.T., and Zuliarni, S. (2014). Pengaruh lokasi usaha pada volumen penjualan (Survei pada restoran kecil di lingkungan Universitas Riau), Jurnal Ilmiah Akuntansi dan Bisnis, 9(2), 92100.

Islam, D. (2018). Tinjauan penerapan konsep green marketing dalam pelestarian lingkungan, Jurnal PAMATOR, 11(1), 10-18.

Istantia, S., Kumadji, S., and Hidayat, K. (2016). Pengaruh green marketing terhadap citra merek dan keputusan pembelian (Survei pada pengguna produk ramah lingkungan lampu Philips LED di Perum Kepanjen Kermai 1, RW 4, Desa talangagung, Kec. Kepanjen, Malang, Jawa Timur), Jurnal Administrasi Bisnis, 32(1).

Kotler, P., and Armstrong, G. (2008). Principles of Marketing. Germany: Pearson/Prentice Hall.

Kotler, P., Keller, K.L., Brady, M., Goodman, M., and Hansen, T. (2019). Marketing Management. UK: Pearson Education Limited.

McQueen, R. A., Knussen, C. (2013). Introduction to Research Methods and Statistics in Psychology: A Practical Guide for the Undergraduate Researcher. UK: Pearson.

Pamikatsih, M. (2019). Analisis pengaruh kualitas produk dan harga terhadap penjualan telur ayam (Studi kasus pada Usaha Dagang KR Farm Cilacap), AmaNU: Jumal Manajemen dan Ekonomi, 2(2).

Priyanka, D., and Septrizola, W. (2019). Pengaruh green product dan green promotion terhadap brand image PT Suzuki Indomobil di Kota Padang, Jurnal Kajian Manajemen dan Wirausaba, 1(1), 344-348. http://dx.doi.org/10.24036/jkmw0255270 
Putripeni, M.P., Suharyono and Kusumawati, A. (2014). Pengaruh green marketing terhadap citra merek dan keputusan pembelian (Studi pada konsumen The Body Shop Mall Olympic Garden Malang), Jurnal Administrasi Bisnis, 10(1), 1-10.

Rahayu, L.M.P., Abdillah, Y., and Mawardi, M.K. (2017). Pengaruh green marketing terhadap keputusan pembelian konsumen (Survei pada konsumen The Body Shop di Indonesia dan Malaysia), Jurnal Administrasi Bisnis, 43(1).

Rahman, F., Siburian, P.S., and Noorlitaria, G.A. (2017). Pengaruh Green Marketing Mix terhadap keputusan pembelian konsumen produk Tupperware di Samarinda, Forum Ekonomi: Jurnal Ekonomi, Manajemen, dan Akuntansi, 19(1), 119-130. http://dx.doi.org/10.29264/jfor.v19i1.2118

Risyamuka, I.K., and Mandala, K. (2015). Pengaruh green marketing terhadap keputusan pembelian produk hijau di Restoran Sari Organik Ubud, E-jurnal Manajemen Unud, 4(2), 524-543.

Sekaran, U., and Bougie, R. (2010). Research methods for business, fifth edition. USA: John Wiley \& Sons.

Shrum, L. J., McCarty, J. A., and Lowrey, T. M. (1995). Buyer characteristics of the green consumer and their implications for advertising strategy, Journal of advertising, 24(2), 71-82.

Syahbandi. (2012). Implementasi green marketing melalui pendekatan marketing mix, demografi dan pengetahuan terhadap pilihan konsumen (Studi The Body Shop Pontianak), Jurnal Ekonomi, Bisnis, dan Kewirausahaan, 3(1), 68-86.

Tjiptono, F. (2005). Brand management and strategy. Yogyakarta: Andi Offset.

Tjiptono, F., and Chandra, G. (2017). Pemasaran strategik, edisi 3. Yogyakarta: Andi Offset.

Verma, J.P. (2012). Data analysis in management with SPSS software. India: Springer. 